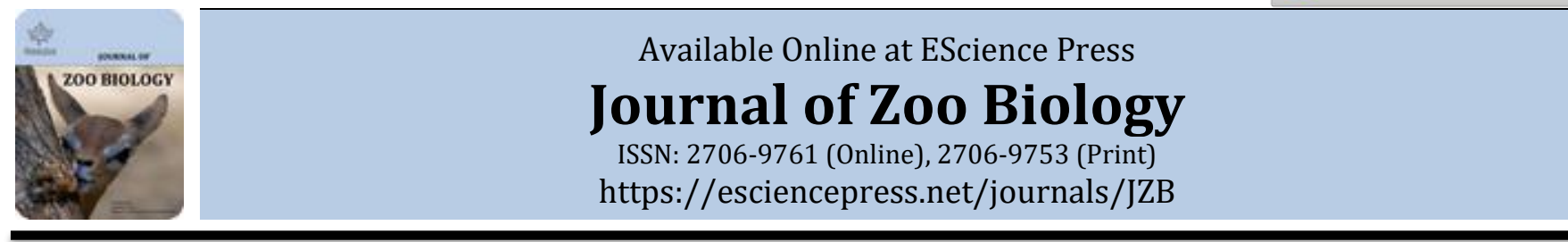

\title{
Biochemical Transition Effects of Fungi Fouling Disease in Penaeus Monodon Shrimp
}

aVelmurugan Karthikeyan*, bSelvaraj Balachandran, bKasilingam Ramachandran, anagarajan Rajesh and aAyyaru Gopalakrishnan

a Center of Advanced Study in Marine Biology, Faculty of Marine Sciences, Annamalai University, Parangipettai 608502, TN, India.

${ }^{b}$ University of Madras, Chennai 600005, TN, India.

\section{ART ICLE INFO}

\section{Article History}

Received: April 08, 2020

Revised: August 17, 2020

Accepted: September 11, 2020

\section{Keywords}

Penaeus monodon

Fungi

Gilbertella persicaria

Biochemical composition

\section{A B S T R A C T}

Penaeus monodon (black tiger shrimp) is one of the most cultured shrimp species in India. Biochemical compositions of such shrimp species play a major role in recent decades. The biochemical composition is an index to assess the nutritional quality of food sources. The present work endeavor is to analyze total protein, carbohydrates, total lipids, amino acids, fatty acids, vitamins and minerals from muscle tissues of both Gilbertella persicaria fungal fouling infected and healthy shrimp, P. monodon. The study animal was captured by cast net operation from cultured grow-out shrimp pond located in Tamil Nadu. The study revealed maximum amounts of nutritional status was observed in healthy shrimp P. monodon (total protein $49.15 \%$, carbohydrate $16.53 \%$, total lipid $2.37 \%$ ) tissues compared with $G$. persicaria fungal fouling infected shrimp (total protein $31.15 \%$, carbohydrate $11.05 \%$, total lipid $1.04 \%$ ) were recorded. These results indicate novel report on nutritional aspect of fungal fouling pathogen $G$. persicaria which has significantly contributed in biochemical composition reduction of P. monodon.

*Corresponding Author: Velmurugan Karthikeyan

Email: karthikeyancansee@gmail.com Tel: +919791368284.

(c) The Author(s) 2020.

\section{INTRODUCTION}

Sea foods products encompass as important sources of nutrients in the human diet which are simply digestible because of the less connective tissue (Yanar and Çelik, 2006). Apart from their delicacy, crustaceans such as shrimps, crabs and lobsters clinch high amount of proteins, lipids and vitamins with wide assortment of minerals without much fat, cholesterol, sodium, metals and low concentration of carbohydrates (González-Félix et al., 2002). Generally, people who consume seafood routinely in their diet are less likely to develop heart diseases, diabetes, arthritis, bronchial, asthma and psoriasis (Chiu and Ni, 2014).

Compared to all other sea foods, shrimps are one among delicious seafood in the world. More than 50 countries have developed shrimp farming, India is one among those leading countries which harvest and export shrimps (Pugalopez et al., 2013). India by virtue of its $7000 \mathrm{kms}$ long coastline has tremendous potential in terms of marine foods resources (Vivekanandan et al., 2005). (Shalini, 2013) reported that healthy shrimps are nutritionally rich than shrimps infected with white spot syndrome virus (WSSV). In Year 2012-2013 many fungal fouling P. monodon shrimps predominantly infected by phytopathogenic fungi G. persicaria were found in grow out farms at Vellapallam coastal areas of Tamil Nadu. It was first time novel report of phytopathogenic fungi G. persicaria infection on P. monodon (Karthikeyan and Gopalakrishnan, 2014). 
Nevertheless, this $P$. monodon being consumed in all countries, no substantial studies have been reported so far in comparison of nutritive values between infected and healthy shrimps. Hence, the present study was aimed to compare the proximate composition of phytopathogenic fungi $G$. persicaria infected and healthy shrimps, $P$. monodon through estimation of major biochemical components such as total protein, carbohydrate, total lipid, vitamins and minerals in the whole body tissue.

\section{MATERIALS AND METHODS}

\section{Study Area}

Vellapallam (Lat.10030'55.65"N; Long.79050'37.04”E) is a coastal area located at Nagapattinam district of Tamil $\mathrm{Nadu}$, India. A total of 133 shrimp grow out farms were in working form at this area between Year 2012 and 2013.

\section{Sample Collection}

The shrimps, P. monodon weighing of about 17 - 30 g were sampled monthly between January 2012 and March 2013 by cast net operation. The fungal fouling infected (Figures 1) and healthy P. monodon were collected from grow-out pond and brought to the laboratory at $4{ }^{\circ} \mathrm{C}$ for further studies. The shrimp's carapace was removed, and tissues were dried at $50{ }^{\circ} \mathrm{C}$ in hot air oven for $24 \mathrm{hrs}$. Further, the dried meat was powdered and used for estimation of total protein, carbohydrate, total lipid, amino acids, fatty acids, vitamins and minerals.

\section{Estimation of protein}

The crude protein amount $\mathrm{mg} / \mathrm{g}$ in the tissue was estimated by kjeldahl method (AOAC, 1997).

\section{Estimation of carbohydrate}

The total carbohydrate amount was estimated by (DuBois et al., 1956) method using Phenol - Sulphuric acid.

\section{Estimation of total lipid}

The total lipid content was estimated by (Floch, 1956) method using chloroform-methanol extraction procedure.

\section{Estimation of amino acids}

For amino acid analysis, the tissue samples were finely powdered and estimated through HPLC (Merck, Hitachi L7400) by adopting the method of (Baker and Han, 1994).

\section{Fatty acid analysis}

For fatty acids analysis, samples were homogenized with chloroform: methanol $(2: 1 \mathrm{v} / \mathrm{v})$ mixture and were extracted using (Bligh and Dyer, 1959) method. After extraction, the fats were esterified with 1\% H2SO4 and fatty acid methyl esters. The identification and quantification of fatty acids was done using Gas chromatography (Hewlett Packard 5890 model).
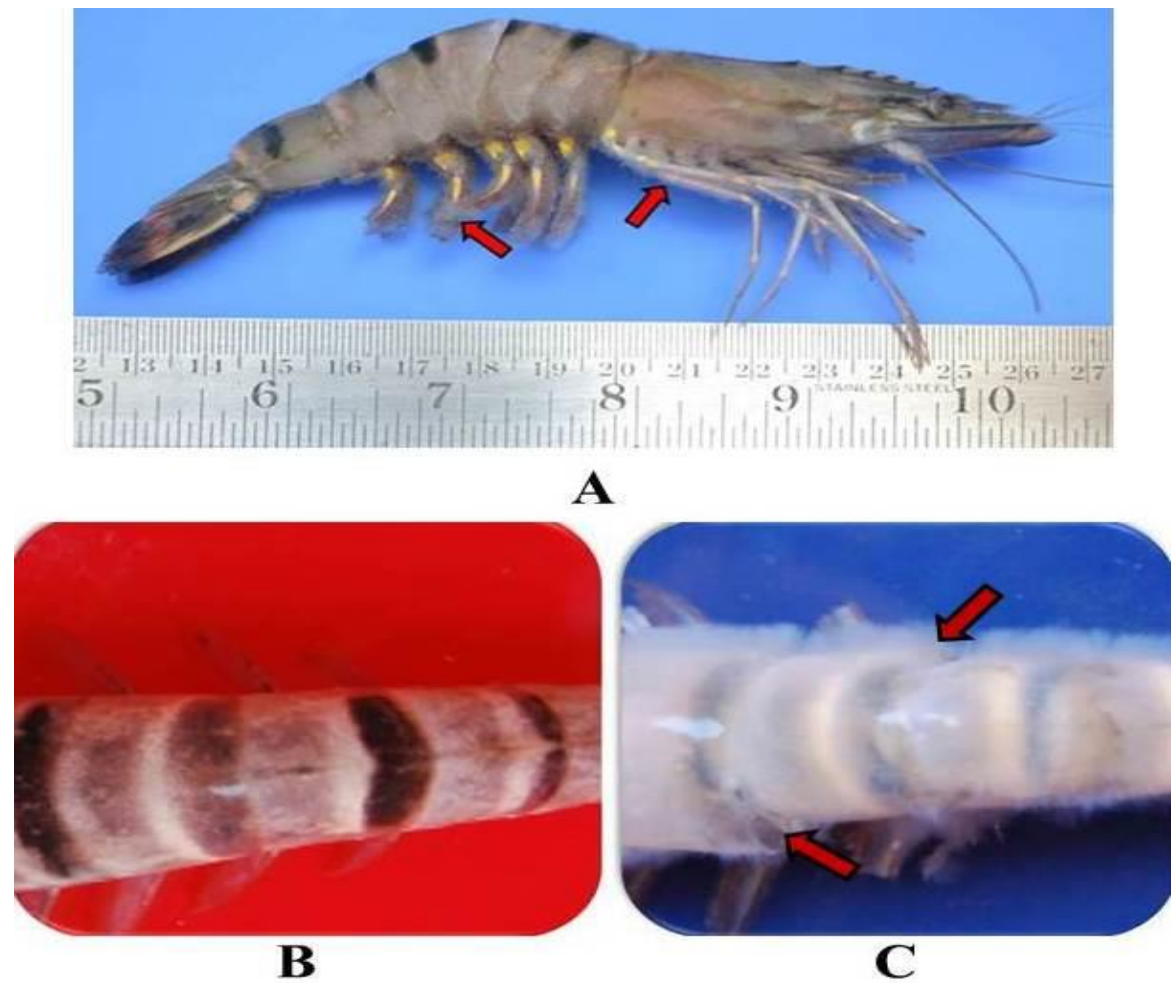

Figure 1. (A)Photograph reveals that the fungal fouled on P. monodon shrimp (B) Close up view of healthy $P$. monodon shrimp (C) Close up view of fungal fouled on P. monodon shrimp. 


\section{Estimation of vitamins}

The fat-soluble vitamins such as A, D, E and $\mathrm{K}$ and watersoluble vitamins namely B1, B2, B6, B12 and C were analyzed through HPLC (Merk Hitachi L-74000) method explained by (Sadasivam, 1996). The folic acid content was estimated by calorimetric method of (Sethi, 1997). Further the pyridoxine, panthothenic acid and vitamin B12 were estimated by USP NF 2000 Asian edition (Srilatha et al., 2013) methods.

\section{Estimation of Minerals}

The minerals were estimated by (Guzmán and Jiménez, 1992) method.

\section{RESULTS}

In present study the proximate composition of tissues of both healthy and fungal infected shrimps were examined. As a result, the protein contents were found to be higher (49.15 and $31.15 \%$ ) followed by carbohydrate (16.53 and $11.5 \%$ ) and lipid (2.37 and 1.04\%) in healthy and infected shrimps, respectively. The percentage composition of essential and non - essential amino acids in healthy shrimp tissues were presented in Table 1).

Table 1. Essential and non-essential amino acid of the tissue of healthy shrimp.

\begin{tabular}{lcll}
\hline \multicolumn{1}{c}{ EAA } & $\begin{array}{c}\text { \% of } \\
\text { amino } \\
\text { acids }\end{array}$ & \multicolumn{1}{c}{ NEAA } & $\begin{array}{c}\text { \% of } \\
\text { amino } \\
\text { acids }\end{array}$ \\
\hline Phenylalanine & 6.91 & Glycine & 3.86 \\
Lysine & 3.24 & Serine & 8.65 \\
Histidine & 7.13 & Glutamic acid & 6.03 \\
Methionine & 4.06 & Cystine & 2.45 \\
Leucine & 14.18 & Glutamine & 4.68 \\
Threonine & 2.96 & Alanine & 0.74 \\
Isoleucine & 6.32 & Proline & 1.94 \\
Valine & 4.18 & Asparagine & 11.03 \\
Tryptophan & 3.84 & Tyrosine & 2.96 \\
$\quad-$ & - & Aspartic acid & 0.24 \\
$\quad$ & - & Arginine & 2.42 \\
\hline
\end{tabular}

The results revealed that the total essential and nonessential amino acids in the healthy shrimp healthy tissues were about 55.84 and $45.0 \%$, respectively on dry matter basis. Similarly, the percentage composition of essential and non-essential amino acids of infected shrimp was found to be about 32.21 and $52.24 \%$, respectively (Table 2 ).

Among the essential amino acids, methionine (4.06 and $0.00 \%$ ), valine (4.18 and $0.31 \%$ ), phenylalanine (6.91 and
$5.36 \%$ ), tryptophan (3.84 and $0.08 \%$ ), leucine (14.18 and $2.16 \%$ ) and lysine (3.24 and 3.15\%) composition were found to be lower in infected shrimps compared to healthy shrimps. Some essential amino acids such as histidine (8.46 and 7.13\%), isoleucine (9.26 and 6.32\%), and threonine (3.45 and 2.96\%) composition were increased considerably in infected shrimps compared to healthy shrimps respectively.

Table 2. Essential and non-essential amino acid in the tissue of infected shrimp.

\begin{tabular}{lcll}
\hline \multicolumn{1}{c}{ EAA } & $\begin{array}{c}\text { \% of } \\
\text { amino } \\
\text { acids }\end{array}$ & \multicolumn{1}{c}{ NEAA } & $\begin{array}{c}\text { \% of } \\
\text { amino } \\
\text { acids }\end{array}$ \\
\hline Phenylalanine & 5.36 & Glycine & 7.54 \\
Lysine & 3.15 & Serine & 2.18 \\
Histidine & 8.46 & Glutamic acid & 12.54 \\
Methionine & 0.00 & Cystine & 6.13 \\
Leucine & 2.16 & Glutamine & 3.62 \\
Threonine & 3.43 & Alanine & 2.18 \\
Isoleucine & 9.26 & Proline & 6.13 \\
Valine & 0.31 & Asparagine & 5.51 \\
Tryptophan & 0.08 & Tyrosine & 1.51 \\
\multicolumn{1}{c}{-} & - & Aspartic acid & 0.39 \\
\hline
\end{tabular}

The non - essential amino acids such as serine (8.64 and $2.18 \%$ ) glutamine (4.68 and $3.62 \%$ ) asparagine (11.03 and $5.51 \%$ ) and tyrosine (2.96 and $1.51 \%$ ) were found to be lower on dry matter basis in fungal infected and healthy shrimps respectively. In addition, there are some non - essential amino acids viz. glycine (3.84 and 7.54\%), glutamic acid (6.03 and 12.54\%), cysteine (2.45 and $6.13 \%)$, alanine (0.74 and $2.18 \%)$, proline (1.94 and $6.13 \%)$, aspartic acid ( 0.24 and $0.39 \%)$, and arginine (2.42 and $4.51 \%$ ) whose compositions were significantly increased in infected dry matter than healthy shrimps. Hence results obtained from present study clearly indicates that, protein content of fungal infected shrimp was comparatively lower than the healthy shrimp due to the $G$. persicaria which completely inhibits the transcription process initiation.

A total of 7 different fatty acids including three saturated fatty acids (SFA), one monounsaturated fatty acids (MUFA) and three polyunsaturated fatty acids (PUFA) were found in fungal infected and healthy shrimps $P$. monodon. The percentage availability of SFA, MUFA and PUFA contents in healthy and fungal infected tissues were about 57.25 and 53.07, 14.96 and 13.60 and 25.63 and 
$18.57 \%$ respectively (Table 3 ). The trivia of vitamins in healthy and infected tissues of shrimp P. monodon were presented in (Table 4). Among the vitamins reported for both healthy and infected tissues, Pyridoxin (B6) (26.78 and 18.87) were seemed to be in higher levels followed by Riboflavin (B2) (0.13 and 0.12).

In addition, the studies include detection of 5 macro and 2 trace minerals in healthy and infected shrimps. The macro minerals in both healthy and infected shrimps were in the order of calcium (345.6 and $156.4 \mathrm{mg} / \mathrm{g}$ ), potassium (345.6 and $103.4 \mathrm{mg} / \mathrm{g}$ ), sodium (234.5 and $145.5 \mathrm{mg} / \mathrm{g}$ ), magnesium (134.7 and $145.3 \mathrm{mg} / \mathrm{g}$ ), copper (4.23 and 1.33 $\mathrm{mg} / \mathrm{g}$ ) zinc (14.1 and $0.33 \mathrm{mg} / \mathrm{g}$ ) and iron (6.96 and 7.01 $\mathrm{mg} / \mathrm{g}$ ) respectively. Hence the study concludes that, macro minerals such as calcium, sodium and potassium were found to be higher in healthy shrimp tissues (Table 5).

Table 3. Fatty acid profile of healthy and infected shrimp tissue.

\begin{tabular}{|c|c|c|c|c|}
\hline S. No & Fatty acids & Carbon atom (n) & Healthy tissue & Infected \\
\hline \multicolumn{5}{|c|}{ Saturated Fatty Acids } \\
\hline 1 & Palmitic acid & C16:0 & 16.22 & 14.88 \\
\hline 2 & Margaric acid & C17:0 & 23.78 & 18.04 \\
\hline 3 & Stearic acid & C18:0 & 17.25 & 20.15 \\
\hline & Total & & 57.25 & 53.07 \\
\hline \multicolumn{5}{|c|}{ Monounsaturated Fatty Acids } \\
\hline 4 & Oleic acid & & 14.96 & 13.6 \\
\hline & Total & & 14.96 & 13.6 \\
\hline \multicolumn{5}{|c|}{ Polyunsaturated Fatty Acids } \\
\hline 5 & Linolenic acid & C18:3 & 14.65 & 11.16 \\
\hline 6 & $\alpha$ - Linolenic acid & C18:3 & 9.46 & 5.38 \\
\hline 7 & Stearidonic acid & C18:4 & 1.52 & 2.03 \\
\hline \multicolumn{3}{|c|}{ Total } & 25.63 & 18.57 \\
\hline \multicolumn{3}{|c|}{ Grand Total } & 97.84 & 85.54 \\
\hline
\end{tabular}

Table 4. The vitamins in healthy and infected tissue of $P$. monodon.

\begin{tabular}{clcc}
\hline $\begin{array}{c}\text { S. } \\
\text { No }\end{array}$ & \multicolumn{1}{c}{ Vitamins } & $\begin{array}{c}\text { Healthy } \\
\text { tissue } \\
(\mathrm{mg} / \mathrm{g})\end{array}$ & $\begin{array}{c}\text { Infected } \\
\text { tissue } \\
(\mathrm{mg} / \mathrm{g})\end{array}$ \\
\hline 1 & Thiamine B1 & 1.08 & 0.22 \\
2 & Riboflavin B2 & 0.13 & 0.12 \\
3 & Pyridoxin (B6) & 26.78 & 18.87 \\
4 & Cobalamin (B12) & 1.63 & 0.88 \\
5 & Ascorbic acid (C) & 0.23 & 0.21 \\
\hline
\end{tabular}

Table 5. The minerals in the tissue of infected and healthy shrimp.

\begin{tabular}{clcc}
\hline $\begin{array}{c}\text { S. } \\
\text { No }\end{array}$ & \multicolumn{1}{c}{ Minerals } & $\begin{array}{c}\text { Healthy } \\
\text { tissue } \\
(\mathrm{mg} / \mathrm{g})\end{array}$ & $\begin{array}{c}\text { Infected } \\
\text { tissue } \\
(\mathrm{mg} / \mathrm{g})\end{array}$ \\
\hline Macro & 345.6 & 156.4 \\
2 & Calcium & 234.5 & 145.5 \\
3 & Sodium & 345.6 & 103.4 \\
4 & Potassium & 4.23 & 1.33 \\
5 & Copper & 134.7 & 145.3 \\
& Magnesium & & \\
6 & Micro & 6.96 & 7.01 \\
7 & Zinc & 14.1 & 0.33 \\
\hline
\end{tabular}

\section{DISCUSSION}

Foods obtained from sea have been a high quality protein source for hundreds of years (Okuzumi, 2000). Among five basic groups, sea foods belong to the same category as meat, poultry, eggs, dried beans and peas as major sources of protein (Dean, 1990). Shrimps are enormously good protein source, yet very low in fat and calories, making them a healthy choice of food (Sriket et al., 2007). In general, the biochemical composition of any organisms is acknowledged to vary with season, size of animal, stages of maturity and availability of food, temperature, etc. (Ravichandran, 2009). Fungal infections are most commonly occurring phenomenon in crustacean species of marine environment (Khoa et al., 2005). In general, black gill circumstance in shrimps caused by Fusarium species develops to "blackened gill" condition thereby leading to death of affected individuals (Khoa, 2005). In present study, proximate compositions of amino acids, fatty acids, vitamins and minerals of both $G$. persicaria infected and healthy shrimps $P$. monodon were investigated. As a result, the protein content was higher than fat and carbohydrate in healthy and infected tissues of P. monodon (49.15 and 31.15\%). Likewise, 
(Narasimhan, 2013)(Narasimhan et al., 2013) reported that the amount of protein contents was higher in muscle $(149.00 \pm 0.65 \mathrm{mg} / \mathrm{g})$ followed by gills $(89.46 \pm 1.26$ $\mathrm{mg} / \mathrm{g})$ and intestine $(114.40 \pm 0.97 \mathrm{mg} / \mathrm{gm})$ of $P$. monodon. Agreeing to the above results, the protein content in tissues of healthy and infected of $P$. monodon was higher with significant variations. Moreover, the carbohydrate contents in healthy and infected $P$. monodon tissues indicate that the healthy shrimps $(16.53 \%)$ contains higher carbohydrate levels than infected shrimps $(11.5 \%)$ tissues owing to fungal load enhancement in their circulatory system. The prospect of high levels of total carbohydrates might be due to transport of glucose and carbohydrate from hepatopancreas and muscles to hemolymph (Zeng et al., 2013). Commonly the carbohydrate levels increased in infected or stressed animals. (Hall and Ham, 1998) reported that significant elevation of blood glucose levels (carbohydrate) in P. monodon occurs during stress conditions. In both healthy and infected shrimp P.monodon tissues the lipid levels achieved are 2.37 and $1.04 \%$ respectively. Likewise, (Zeng et al., 2013) have reported that lipid levels are higher in the mid gut due to intake of additional diet. In healthy shrimp tissues, essential amino acids such as leucine (9.78\%) and tryptophan $(0.12 \%)$ were found in higher and lower levels.

Similarly, the nonessential amino acids such as glutamate $(8.15 \%)$ and alanine $(0.13 \%)$ were found in higher and lower levels respectively. As a result, one of major essential amino acid "methionine" was found to be not present in amino acid profile of infected shrimp. Methionine $(\alpha-$ amino $\beta$-methylmercaptobutyrate, symbol met or shortly M) is one of essential amino acid cannot be synthesized by humans and other animals available only in food sources having positively charged sulfur groups (and is thus a sulfonium ion), is a powerful methylating agent essential as a donor of active methyl group. Also it is involved in important biochemical metabolisms, formation of methionyl tRNA, Nformylmethionyl tRNA, $S$ - adenosylmethionine homocysteine, cysteine, creatine, phosphatidyl choline, methylated derivatives of DNA, RNA, proteins, catechol amines and carnitine (Mudd and Poole, 1975) (Hoshino et al., 2004; Jain, 2005; Murray, 1998). At rare conditions diminished levels of methionine inhibits protein synthesis. Inability to absorb methionine from gut leads to methionine malabsorption syndrome (Murray, 1998).
(Sriket et al., 2007) stated that arginine was the most abundant amino acids while leucine, isoleucine and proline were prime in all shrimps and prawns. (Simpson et al., 1998) have found that there is a high level of glycine, proline, arginine, and valine amino acids in fresh Pandalus borealis shrimp meat. Hence this study clearly divulges that, the fouling infection by a phytopathogenic fungi G. persicaria might drastically reduced the methionine production in shrimp which in turn affects the host's protein synthesis.

The present study also reveals that in healthy tissues of $P$. monodon three saturated fatty acids (SFA), one monounsaturated fatty acids (MUFA) and three polyunsaturated fatty acids (PUFA) were reported. The percentage availability of SFA, MUFA and PUFA content in healthy shrimp tissues were about 57.25, 14.96 and $25.63 \%$, whereas in infected shrimp tissues it was about 53.07, 13.6 and $18.57 \%$ respectively. Similarly, (Pugalopez et al., 2013) reported that low SFA and MUFA amounts were found in WSSV infected L. vannamei shrimp tissues. Moreover this study implies that maximum amount of oleic acid (14.96\%) reported in healthy shrimp tissues likely equivalent to linoleic acid level traces present in the WSSV infected shrimp tissue when compared to healthy L.vannamei (Zeng et al., 2013). Further experimental studies showed, vitamin $\mathrm{B}_{6}$ dominance in both healthy $(26.78 \mathrm{mg} / 100 \mathrm{~g})$ and infected tissues $(18.87 \mathrm{mg} / 100 \mathrm{~g})$, whereas vitamin $\mathrm{B}_{2}$ were found at lower levels in both healthy and infected tissues $(0.13$ and $0.12 \mathrm{mg} / 100 \mathrm{~g}$ ) correspondingly. A total of 5 macro and 2 trace minerals were reported in infected as well as healthy shrimp tissues. Among macro minerals reported calcium $(345.6 \mathrm{mg} / \mathrm{g})$, potassium $(345.6 \mathrm{mg} / \mathrm{g})$, sodium $(234.5 \mathrm{mg} / \mathrm{g})$ and copper $(0.45 \mathrm{mg} / \mathrm{g})$ were observed at higher levels in healthy tissues compared to infected shrimps. (Ravichandran, 2009) reported in shell and flesh the sodium (29 and $38.6 \mathrm{mg} / 100 \mathrm{~g}$, potassium $(24.3$ $\mathrm{mg} / 100 \mathrm{~g}$ and $33.2 \mathrm{mg} / 100 \mathrm{~g}$ ), phosphorus (82.4 and 91.5 $\mathrm{mg} / 100 \mathrm{~g}$ ) levels of shrimp P. indicus.

Though the $P$. monodon shrimp possesses significant nutritive values as well found to be a good source of protein and Omega- 3 and 6 polyunsaturated fatty acids, the fungal fouling pathogen $G$. persicaria significantly contributed in reduction of its biochemical composition. Conclusively, the infection of $G$. persicaria inhibits the synthesis of initiating codon amino acid "methionine" which is responsible for protein synthesis. Hence, the results revealed that continuous G. persicaria 
infection leads to stunted growth at shrimps grow out farms resulting in less survival rate and poor marketability.

\section{ACKNOWLEDGEMENTS}

Authors are thankful to Dr. T. Balasubramanian, former Dean and Director, Center of Advanced Studies in Marine Biology, Faculty of Marine Sciences, Annamalai University for the provided giving facilities and encouragement during the study period.

\section{CONFLICT OF INTEREST}

All authors declare that there is no conflict of interest.

\section{AUTHOR'S CONTRIBUTION}

All authors contributed equally to this research work.

\section{REEFERENCES}

AOAC. 1997. Official methods of analysis of AOAC International, 16th ed. Choice Reviews Online 35: 35-0912-0935-0912.

Baker, D. H. and Y. Han. 1994. Ideal Amino Acid Profile for Chicks During the First Three Weeks Posthatching. Poultry Science 73: 1441-1447.

Bligh, E. G. and W. J. Dyer. 1959. A RAPID METHOD OF TOTAL LIPID EXTRACTION AND PURIFICATION. Canadian Journal of Biochemistry and Physiology 37: 911-917.

Chiu, M. and C. Ni. 2014. Psoriasis and comorbidities: links and risks. Clinical, Cosmetic and Investigational Dermatology: 119.

Dean, L. M. 1990. Nutrition and Preparation, The Seafood Industry. Springer US, pp. 255-267.

DuBois, M., K. A. Gilles, J. K. Hamilton, P. A. Rebers and F. Smith. 1956. Colorimetric Method for Determination of Sugars and Related Substances. Analytical Chemistry 28: 350-356.

Floch, J., Lees, M., and Sloane-Stanley, G.H. 1956. A simple method for the isolation and purification of total lipids from animal tissues. Journal Biological Chemistry 226: 497-509.

González-Félix, M. L., D. M. Gatlin, A. L. Lawrence and M. Perez-Velazquez. 2002. Effect of dietary phospholipid on essential fatty acid requirements and tissue lipid composition of Litopenaeus vannamei juveniles. Aquaculture 207: 151-167.

Guzmán, H. M. and C. E. Jiménez. 1992. Contamination of coral reefs by heavy metals along the Caribbean coast of Central America (Costa Rica and Panama). Marine Pollution Bulletin 24: 554-561.

Hall, M. R. and E. H. Ham. 1998. The Effects of Different Types of Stress on Blood Glucose in the Giant Tiger Prawn Penaeus monodon. Journal of the World Aquaculture Society 29: 290-299.

Hoshino, Y., A. Mukai, K. Yazawa, J. U. N. Uno, A. Ando, Y. Mikami, T. Fukai, J. U. N. Ishikawa and K. Yamaguchi. 2004. Transvalencin A, a Thiazolidine Zinc Complex Antibiotic Produced by a Clinical Isolate of Nocardia transvalensis: II.Structure Elucidation. The Journal of Antibiotics 57: 803-807.

Jain, J. L., Jain, S., and Jain, N. 2005. Fundamentals of biochemistry, 6th ed. S. Chand and company Ltd, New Delhi.

Karthikeyan, V. and A. Gopalakrishnan. 2014. A novel report of phytopathogenic fungi Gilbertella persicaria infection on Penaeus monodon. Aquaculture 430: 224-229.

Khoa, L. V. 2005. Studies on Fusarium of cultured prawns in Vietnam and Japan. Nippon Veterinary and Animal Science University, Tokyo, Japan, p. 189.

Khoa, L. V., K. Hatai, A. Yuasa and K. Sawada. 2005. Morphology and Molecular Phylogeny of Fusarium solani Isolated from Kuruma Prawn Penaeus japonicus with Black Gills. Fish Pathology 40: 103109.

Mudd, S. H. and J. R. Poole. 1975. Labile methyl balances for normal humans on various dietary regimens. Metabolism 24: 721-735.

Murray, R. K., Granner, D.K., Mayes, P.A., and Rodwell, V.W. . 1998. A large medical book Harper`s biochemistry, 24th ed. Prentice hall international, India.

Narasimhan, N., Maharajothi, P., Ravichelvan, R., Sukumaran M., and Ravichandran, R., . 2013. Biochemical studies on protein content in different tissues of selected shrimps Penaeus monodon and Penaeus vannamei. International Journal Pure and Applied Zoology 1: 113-117.

Okuzumi, M., and Fujii, T. . 2000. Nutritional and functional properties of squid and cattle fish. 35th anniversary of commemorative publication: 223 .

Puga-lopez, D., J. T. Ponce-palafox, G. Barba-quintero, M. R. Torres-herrera, E. Romero-beltran, J. L. Arredondo-figueroa and M. G.-u. Gomez. 2013. Physicochemical, Proximate Composition, Microbiological and Sensory Analysis of Farmed 
and Wild Harvested White Shrimp $<$ em>Litopenaeus vannamei</em> (Boone, 1931) Tissues. Current Research Journal of Biological Sciences 5: 130-125.

Ravichandran, S. 2009. Biochemical composition of shell and flesh of the Indian white shrimp Penaeus indicus (H. Milne Edwards, 1837). AmericanEurasian Journal of Scientific Research 4: 191-194.

Sadasivam, S., and Manickam, A. 1996. Biochemical Methods, 2nd ed. New Age International (p) limited Publishers,.

Sethi, P. D. 1997. Quantitative analysis of drugs in pharmaceutical formulations, 3rd ed. Unique Publishers.

Shalini, R., Nazar, A.R., Badhul Haq, M.A., and Shanker, S. 2013. Biochemical changes of Litopenaeus vannamei and Fenneropenaeus indicus in the different stages of WSSV infection. Journal of Coastal Life Medicine.

Simpson, B. K., G. Nayeri, V. Yaylayan and I. N. A. Ashie. 1998. Enzymatic hydrolysis of shrimp meat. Food Chemistry 61: 131-138.

Sriket, P., S. Benjakul, W. Visessanguan and K. Kijroongrojana. 2007. Comparative studies on chemical composition and thermal properties of black tiger shrimp (Penaeus monodon) and white shrimp (Penaeus vannamei) meats. Food Chemistry 103: 1199-1207.

Srilatha, G., K. Chamundeeswari, K. Ramamoorthy, G. Sankar and D. Varadharajan. 2013. Proximate, Amino Acid, Fatty Acid and Mineral Analysis of Clam, Meretrix casta (Chemnitz) from Cuddalore and Parangipettai Coast, South East Coast of India. Journal of Marine Biology \& Oceanography 02.

Vivekanandan, E., M. Srinath and S. Kuriakose. 2005. Fishing the marine food web along the Indian coast. Fisheries Research 72: 241-252.

Yanar, Y. and M. Çelik. 2006. Seasonal amino acid profiles and mineral contents of green tiger shrimp (Penaeus semisulcatus De Haan, 1844) and speckled shrimp (Metapenaeus monoceros Fabricus, 1789) from the Eastern Mediterranean. Food Chemistry 94: 33-36.

Zeng, D., X. Chen, D. Xie, Y. Zhao, C. Yang, Y. Li, N. Ma, M. Peng, Q. Yang, Z. Liao, H. Wang and X. Chen. 2013. Transcriptome Analysis of Pacific White Shrimp (Litopenaeus vannamei) Hepatopancreas in Response to Taura Syndrome Virus (TSV) Experimental Infection. PLoS ONE 8: e57515.

Publisher's note: EScience Press remains neutral with regard to jurisdictional claims in published maps and institutional affiliations.

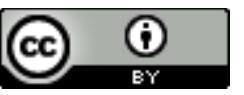

Open Access This article is licensed under a Creative Commons Attribution 4.0 International License, which permits use, sharing, adaptation, distribution and reproduction in any medium or format, as long as you give appropriate credit to the original author(s) and the source, provide a link to the Creative Commons license and indicate if changes were made. The images or other third-party material in this article are included in the article's Creative Commons license, unless indicated otherwise in a credit line to the material. If material is not included in the article's Creative Commons license and your intended use is not permitted by statutory regulation or exceeds the permitted use, you will need to obtain permission directly from the copyright holder. To view a copy of this license, visit http://creativecommons.org/licenses/by/4.0/.

(C) The Author(s) 2020. 